\title{
PENGARUH SUPERVISI DAN KOMPENSASI TERHADAP KINERJA YANG DI MEDIASI VARIABEL MOTIVASI KERJA GURU SMA NEGERI 1 MAUMERE
}

\author{
Mohamad Amir \\ Department of Management FEB UMM \\ E-mail: amirsahdat@gmail.com
}

\begin{abstract}
This study aims to determine 1) Effect of supervision of principals on work motivation of teachers in SMA Negeri 1 Maumere. 2) The effect of compensation on work motivation of teachers in SMA Negeri 1 Maumere. 3) Effect of supervision of principals on teacher performance in SMA Negeri 1 Maumere. 4) Effect of compensation to the performance of teachers in SMA Negeri 1 Maumere. 5) The effect of work motivation on teacher performance in SMA Negeri 1 Maumere. 6) Role of Motivation as a mediating influence supervision of principals on teacher performance in SMA Negeri 1 Maumere. 7) The role of motivation to work as a mediating influence of compensation on teacher performance in SMA Negeri 1 Maumere. Analysis of the data used in the study using Path Analysis (path analysis) which is the application of multiple regression using the path diagram as a guide t test the hypothesis testing as a basis for decision making in determining the direct and indirect effects of research dependent and independent variables.
\end{abstract}

Keywords: supervision, compensation, motivation, performance

\section{PENDAHULUAN}

Meningkatkan kualitas lembaga pendidikan, dibutuhkan peran sumber daya manusia handal yang tergabung didalam lembaga sekolah itu, Tilaar (2004) peningkatan kualitas pendidikan tergantung banyak hal, terutama mutu gurunya. Peranan guru sangat menentukan dalam usaha peningkatan mutu pendidikan. Untuk itu guru sebagai agen pembelajaran dituntut untuk mampu menyelenggarakan proses pembelajaran dengan sebaikbaiknya, dalam kerangka pembangunan pendidikan. Guru mempunyai fungsi dan peran yang sangat trategis dalam pembangunan bidang pendidikan, dan oleh karena itu perlu dikembangkan sebagai profesi yang bermartabat. Undang Undang No. 14 tahun 2005 tentang Guru dan Dosen Pasal 4 meyiratkan bahwa guru sebagai agen pembelajaran berfungsi untuk meningkatkan mutu pendidikan nasional.

Berkaitan dengan peran pendidikan maka sekolah sebagai suatu sistem sosial di dalamnya terdapat interaksi sosial. Menurut Gaffar (2005) sekolah harus dikelolah dengan baik agar dapat memenuhi kebutuhan dan mencapai 
tujuan sekolah. Keberhasilan pencapaian tujuan pendidikan dan pengajaran di sekolah tidak hanya ditentukan oleh guru - guru atau staf lainnya, tetapi peranan kepala sekolah sangat menentukan dalam menciptakan iklim sekolah yang mendukung pelaksanaan proses belajar mengajar. Untuk itu peran kepala sekolah sangat penting dalam hal pembinaan secara terus menerus dan berkesinambungan..

Gani (2005) menyimpulkan bahwa ada pengaruh yang signifikan antara variable perilaku tugas, perilaku hubungan, gaji, kompensasi pelengkap dan insentif yang diterima guru terhadap prestasi kerja guru. Aritonang (2005) menyimpulkan bahwa kompensasi kerja memberikan sumbangan sebesar $6,76 \%$ terhadap kinerja guru. Suparwati (1999) menyimpulkan bahwa faktor - faktor kompensasi seperti gaji, insentif, kesejahteraan dan promosi berpengaruh terhadap kinerja dosen..

Kinerja guru dalam suatu institusi pendidikan merupakan faktor yang menarik untuk diteliti karena lima alasan : pertama, guru merupakan ujung tombak bagi keberhasilan belajar mengajar, tanpa guru yang berkualitas dan rela berkorban, mustahil suatu proses belajar mengajar dapat menghasilkan peserta didik yang berkualitas. Kedua, guru tidak hanya dalam mentransfer ilmu kepada siswa tetapi memberikan contoh, sikap, ucapan dan perilaku kepribadian. Ketiga, kualitas kinerja guru bukanlah suatu yang final dan tidak dapat diperbaiki karena sebagai manusia, guru selalu tumbuh dan berubah. Keempat, jika kinerja guru tidak didukung oleh kompetensi profesional dan komunikasi antarpribadi, kepemimpinan kepala sekolah, sistem imbalan/kompensasi untuk guru, dan iklim sekolah, maka proses belajar mengajar tidak bisa lancar sesuai yang diharapkan. Kelima, guru wajib memiliki akademik, kompetensi, sertifikasi pendidik, sehat jasmani dan rohani serta memiliki kemampuan untuk mewujudkan tujuan pendidikan nasional (pasal 8, UUGD 14/2005).

Tujuan dari penelitian ini adalah untuk mengetahui apakah ada pengaruh Supervisi Dan Kompensasi Terhadap Kinerja Yang Di Mediasi Variabel Motivasi Kerja Guru SMA Negeri 1 Maumere.

\section{TINJAUAN PUSTAKA}

Irham (2010) menyatakan bahwa kinerja adalah hasil yang diperoleh suatu organisasi tersebut bersifat profit oriented dan non profit oriented yang dihasilkan selama satu periode waktu. Sedangkan menurut Wirawan (2009) kinerja adalah keluaran yang dihasilkan oleh fungsi - fungsi atau indikator - indikator suatu pekerjaan atau suatu profesi dalam waktu tertentu. Selanjutnya Mangkunegara mendefinisikan kinerja sebagai hasil kerja secara kualitas yang dicapai oleh seorang pegawai dalam melaksanakan tugasnya sesuai dengan tanggung jawab yang diberikan.

Berdasarkan tabel dapat dijelaskan bahwa indeks persepsi rata-rata responden terhadap motivasi sebesar 4,18. Hal ini berarti persepsi responden berkaitan dengan motivasi dipersepsikan baik, artinya guru akan termotivasi apabila semua 
kebutuhannya terpenuhi, seperti kebutuhan akan kekuasaan, kebutuhan akan afiliasi dan kebutuhan akan prestasi.

Berdasarkan indikator yang ada, indikator kebutuhan akan kekuasaan memiliki nilai rata-rata sebesar 4,17. Hasil ini menunjukan bahwa responden memberikan persepsi baik untuk berupaya tidak ketinggalan dalam prestasi, berupaya mengembangkan diri, berupaya untuk mendapatkan pengakuan dari hasil kerja, bersemangat untuk mendapatkan informasi terkini dan mampu menghadapi kesulitan.

Indikator tentang kebutuhan akan afiliasi memiliki nilai rata-rata sebsar 4,04. Hasil ini menunjukan bahwa responden memberikan persepsi baik untuk berafiliasi dengan lingkungn sekolah, bersemangat untuk dapat berkerja sama,berusaha untuk menjaga persahabtan dengan teman sekrja dan berusaha menghormati pimpinan.

Indikator kebutuhan akan prestasi memiliki nilai rata-rata sebesar 4,33. Hasil ini menunjukan bahwa responden memberikan persepsi baik untuk berusaha agar dihargai, berupaya untuk tidak diremehkan, kehadiranya sangat diperlukan dan menjaga kewibaan.

Berdasarkan indikator motivasi, indikator kebutuhan akan prestasi merupakan indikator terkuat membentuk motivasi, artinya guru akan termotivasi apabila kebutuhan akan prestasinya meningkat, dimana guru akan berprestasi di lingkungan sekolah, bersemangat untuk dapat bekerja sama, berusaha agar dihargai, berupaya untuk tidak diremehkan dan prestasinya bisa dipertahankan untuk menjaga kewibaan.
Kinerja guru adalah hasil kerja yang ditampilkan guru-guru dalam melaksanakan tugas-tugas dan tanggung jawabnya, yang meliputi: kemampuan penyelenggaraan pengajaran, kemampuan professional dan kemampuan personal.

Kinerja guru dalam kajian ini didasarkan pada peraturan pemerintah No 16 Tahun 2005 tentang Standar Nasional Pendidikan yaitu persiapan mengajar, implementasi program, evaluasi dan mengembangkan diri.

Berdasarkan indikator yang ada, indikator persiapan mengajar memilik nilai rata-rata sebesar 4.04. Hail ini menunjukan bahwa responden memberikan persepsi baik bahwa kinerja guru yang baik apabila mampu melakukan persiapan mengajar dengan baik, seperti sebelum mengajar merencanakan pengajaran, melakukan analisis karakteristik siswa sebelum menyusun RPP, berusaha menyediakan sumber-sumber belajar yang sesuai dengan tujuan pengajaran untuk merangsang kegiatan belajar siswa dan sebelum mengajar, membuat analisis pelajaran dan silabus pembelajaran.

Indikator tentang implementasi program kerja memiliki nilai ratarata sebesar 4,17. Hasil ini menunjukan bahwa responden memberikan persepsi baik bahwa kinerja guru yang baik apabila mengadakan dialog dengan siswa untuk menggalakan aktifitas belajarnya, mengajukan pertanyaan untuk memancing siswa, memberikan penjelasan tentang tujuan yang akan dicapai dalam pembelajaran, penjelasan materi pelajaran lebih menarik dengan 
mendemonstrasikan materi contoh dan memberikan penjelasan ualang dan beberapa petunjuk apabila siswa salah mengerti.

Indikator evaluasi memiliki nilai rat-rata sebesar 4,07. Hasil ini menunjukan bahwa responden memberikan persepsi baik bahwa kinerja guru yang baik apabila memberikan tugas untuk memperdalam isi materi pembelajaran, memeriksa dan menilai tugas siswa dan mengembalikan tugas siswa yang telah diperiksa.

Indikator mengembangkan profesi memiliki nilai rata-rata sebesar 4,13. Hasil ini menunjukan bahwa responden memberikan persepsi baik bahwa kinerja guru yang baik apabila melakukan analisis daya serap dan ketuntasan belajar siswa setiap selesai ulangan, melakukan analisis target pencapaian kurikulum setiap selesai, melakukan analisis butir soal setiap selesai ulangan dan membantu dan membimbing siswa yang mengalami kesulitan belajar.

\section{METODE PENELITIAN}

Berdasarkan indikator kinerja, indikator implementasi program kerja dan mengembangkan profesi merupakan indikator terkuat membentuk kinerja guru, artinya guru akan memiliki kinerja yanbaik apabila mampu melakukan implementasi mengajar dengan baik, mampu mengimplementasikan program kerja, mampu mengadakan evaluasi dan mengembangkan profesi, melakukan analisis daya serap dan ketuntasan belajar siswa setiap selesai ulangan, melakukan analisis butir soal setiap selesai ulangan dan membantu dan membimbing siswa yang mengalami kesulitan belajar.

Evaluasi terhadap asumsi yang harus dipenuhi dalam prosedur pengumpulan dan pengolahan data yang analisis dengan pemodelan path analysis akan dijelaskan sebagai berikut.Uji linieritas menggunakan curve fit, dimana model dikatakan signifikasi apabila $\mathrm{p}$ value kecil, yaitu dibawah 0,05 .

Tabel 1. Hasil Uji Linieritas Hubungan Antar Variabel

\begin{tabular}{ccc}
\hline Variabel & P Valve & Keterangan \\
\hline Supervisi $\rightarrow$ Motivasi Kerja & 0,000 & Linier \\
Kompensasi $\rightarrow$ Motivasi Kerja & 0,000 & Linier \\
Supervisi $\rightarrow$ Kinerja & 0,000 & Linier \\
Kompensasi $\rightarrow$ Kinerja & 0,000 & Linier \\
Motivasi Kerja $\rightarrow$ Kinerja & 0,000 & Linier \\
\hline
\end{tabular}

Berdasarkan Tabel 1, dapat dilakukan bahwa model membentuk linier, hal ini dibuktikan dengan nilai $\mathrm{p}$ value kecil, yaitu dibawah 0,05 . Model empirik dalam penelitian inimenunjukan aliaran kausal satu arah. Dengan demikian dapat dikatakan bahwa model tersebut berbentuk rekursif sehingga memenuhi asumsi path analysis. Pengukuran variabel penelitian menggunakan skala Likert, menurut sekaran dalam Solimun (2002) skala likert dapat menghasilkan data interval. Berdasarkan pendapat tersebut maka skala pengukuran dalam penelitian ini telah memenuhi asumsi path analysis. 
Hasil pengukuran instrument penelitian telah menunjukan nilai yang valid dan reliabel. Dengan demikian dapat dikatakan bahwa observe variable telah diukur tanpa ada kesalahan, yang dapat diartikan bahwa ukuran tersebut telah memenuhi asumsi analisis jalur.

Model teoritikal dasar dan model empirik dalam penelitian ini dikembangkan berdasarkan telah pustaka dan jurnal ilmiah,sehingga tingkat kebenaran konsep yang dikemukakan dapat dipercaya.
Berdasarkan kenyataan tersebut maka asumsi analisis jalur yang mensyaratkan bahwa model dispesifikasi sesuai dengan teori telah terpenuhi.

Koefisien determinasi total menunjukan bahwa seberapa besar variabel dependen dapat dijelaskan oleh variabel independen yang ada pada model penelitian. Untuk menentukan total koefisien determinasi hasil analis jalur, digunakan rumus sebagai berikut:

$$
R_{m}^{2}=1-P_{e 1}^{2} \cdot P_{e 2}^{2} \cdot P_{e p}^{2}
$$

Tabel 2. Nilai Koefisien Korelasi dan Koefisien Determinasi

\begin{tabular}{ccc}
\hline Variabel & $\mathrm{R}$ & $\mathrm{R}$ square \\
\hline $\begin{array}{c}\text { Supervisi dan kompensasi } \\
\text { terhadap motivasi kerja }\end{array}$ & 0,830 & 0,688 \\
$\begin{array}{c}\text { Supervisi, kompensasi dan } \\
\text { motivasi kerja terhadap } \\
\text { kinerja }\end{array}$ & 0,955 & 0,913 \\
\hline
\end{tabular}

Berdasarkan Tabel 2. di atas, nilai koefisien determinasi $\left(\mathrm{R}^{2}\right)$ terhadap variabel dependen motivasi (Z) adalah 0,688. Hal ini berarti bahwa seluruh variabel independen yakni variabel supervisi (X1) dan variabel kompensasi (X2) dapat menjelaskan variabel dependen motivasi kerja (Z) sebesar 68,8\%.

Dengan demikian variabel lain yang menjelaskan variabel dependen motivasi kerja dan tidak diperhitungkan dalam model sebesar $31,2 \%$ sehingga dapat disimpulkan bahwa model ini layak. Demikian pula jika dilihat dari nilai koefisien korelasi (R) model ini yaitu sebesar 0,830 . Hal ini berarti variabel dependen motivasi kerja (Z) hubungannya cukup kuat dengan variabel-variabel independen: supervisi (X1) dan kompensasi (X2). Nilai koefisien determinasi $\left(\mathrm{R}^{2}\right)$ terhadap variabel dependen kinerja (Y) adalah 0,913. Model ini dapat dikatakan sangat layak karena $91.3 \%$ variabel (Y) dapat dijelaskan oleh variabel supervisi (X1), kompensasi (X2) dan motivasi (Z). Sisanya adalah sebesar $8,7 \%$ dijelaskan oleh variabel lain yang ada di luar model penelitian dan error.

\section{HASIL PENELITIAN DAN PEMBAHASAN}

Pembahasan ini mengkaji pengaruh supervisi kepala sekolah dan kompensasi terhadap motivasi kerja guru dan mengkaji pengaruh supervisi kepala sekolah, kompensasi dan motivasi kerja terhadap kinerja guru, serta mengkaji peran motivasi kerja sebagai mediasi pengaruh supervisi kepala sekolah dan kompensasi terhadap kinerja guru di SMA Negeri I Maumere. 
Tabel 3. Hasil Uji Hipotesis

\begin{tabular}{lcccc}
\hline \multicolumn{1}{c}{ Hipotesis $(\mathrm{H})$} & Sig & Nilai a & Sig $\rightarrow$ a & Hasil H \\
\hline H1 Supervisi $\rightarrow$ Motivasi & 0,144 & 0,005 & Sig $>$ a & H1 tidak signifikan \\
H2 Kompensasi $\rightarrow$ Motivasi & 0,710 & 0,005 & Sig > a & H2 tidak signifikan \\
H3 Supervisi $\rightarrow$ Kinerja & 0,000 & 0,005 & Sig $<$ a & H3 signifikan \\
H4 Kompensasi $\rightarrow$ Kinerja & 0,065 & 0,005 & Sig > a & H4 tidak signifikan \\
H5 Motivasi $\rightarrow$ Kinerja & 0,000 & 0,005 & Sig $<$ a & H5 signifikan \\
H6 Motivasi $\rightarrow$ Supervisi \& & $-0,695$ & 0,005 & Sig > a & H6 signifikan \\
Kinerja & & & & Hig signifikan \\
H6 Kompetisi $\rightarrow$ Kompensasi \& & $-0,009$ & 0,005 & Sig $<$ a & H7 sinerja \\
Kinerja
\end{tabular}

Dari Tabel 3. dapat diketahui bahwa supervisi kepala sekolah tidak berpengaruh signifikan yang terhadap motivasi kerja guru SMA Negeri I Maumere. Hal ini dapat dijelaskan bahwa kepala sekolah dalam memberikan supervisi selama ini tidak berdampak positif terhadap motivasi kerja guru. Seperti yang diungkapkan ametembun (1981) supervisi pendidikan merupakan pembinaan ke arah perbaikan situasi pendidikan.

Pembinaan yang dimaksud berupa bimbingan atau tuntunan kearah perbaikan situasi pendidikan (pendidikan pengajaran) pada umumnya dan peningkatan mutu mengajar dan menjaga keselarasan antara tujuan-tujuan kepentingan pribadi (personal needs) dan tujuantujuan organisasi (institusional goals) melalui kerja team dan evaluasi terhadap sasaran supervisi.

Seharusnya Kepala sekolah yang mampu menggunakan pendekatan perilaku supervisi dengan baik seperti melakukan kunjungan kelas (observasi kelas) secara teratur, mengadakan pertemuan atau rapat dan mengadakan diskusi kelompok, menjadikan guru termotivasi untuk melakukan pekerjaan dengan baik.

Hasil penelitian ini tidak mendukung kajian yang dilakukan oleh sahertian (2000) bahwa pelaksanaan supervisi bertujuan memberikan pelayanan dan bantuan untuk mengembangkan situasi belajar mengajar yang dilakukan oleh guru dikelas. Keefektifan pelaksanaan supervisi dapat terjadi jika dalam perencanaan dan teknik pelaksanaanya telah dirancang sesuai kebutuhan dan permasalahn yang dialami guru, sehingga guru akan merasakan dampak dari supervisi sebagai pembinaan yang profesional.

Tabel 3. juga menunjukan bahwa kompensasi tidak berpengaruh positif terhadap motivasi kerja guru SMA Negeri 1 Maumere. Hal ini seharusnya dapat dijelaskan bahwa kompensasi bagi organisasi pendidikan berarti penghargaan pada guru yang telah memberikan kontribusi dalam mewujudkan tujuan pendidikan melalui kegiatan yang disebut mengajar atau bekerja (Griffin \& Moorhead, 1996:418).

Pengertian tersebut mengisyaratkan adanya dua pihak yang menanggung kewajiban yang berbeda, tetapi saling mempengaruhi dan saling menentukan. Pihak pertama adalah guru yang berkewajiban dan bertanggung jawab melaksanakan kegiatan yang disebut mengajar. Pihak kedua 
adalah organisasi yang menanggung kewajiban dan tanggung jawab memberikan penghargaan atau ganjaran atas pelaksanaan pekerjaan oleh pihak pertama. Kewajiban dan tanggung jawab muncul karena adanya hubungn kerja diantara kedua belah pihak didalam organisasi pendidikan.

Dari uraian tersebut dapat dijelaskan bahwa peningkatan motivasi kerja guru akan terjadi apabila intitusi mengembangkan kebijakan pemberian sistem kompensasi yang didistribusikan secara adil. Artinya, gaji, insentif, dan tunjangan sesuai yang diharapkan begitu juga dengan lingkungan kerja dan pekerjaan itu sendiri.

Hasil kajian ini tidak mendukung kajian yang dilakukan oleh Ghazanfar, dkk (2011), bahwa kepuasan dengan kompensasi dapat menjadi faktor motivasi kerja. Randy, dkk (2002) menunjukan bahwa kompensasi mampu meningkatkan memotivasi karyawan. Muljani (2002) menyimpulkan bahwa jika program kompensasi dirasakan adil dan kompeetitif oleh karyawan, maka perusahaan akan lebih mudah untuk menarik karyawan yang potensial, mempertahankannya dan memotivasi karyawan agar lebih meningkatkan kinerjanya, sehingga produktifitas meningkat dan perusahaan mampu menghasilkan produk dengan harga yang kompetitf. Pada akhirnya, perusahaan bukan hanya unggul dalam persaingan, namun juga mampu mempertahankan kelangsungan hidupnya, bahkan mampu meningktkan profitabilitas dan mengembangkan usahanya.

Dari hasil analisis data dan pengujian hipotesis menunjukan bahwa supervisi kepala sekolah berpengaruh terhadap kinerja guru SMA Negeri 1 Maumere. Hal ini dapat dijelaskan bahwa peningkatan kinerja guru dapat dicapai melalui peran supervisi kepala sekolah, artinya kepala sekolah mampu menggunakan pendekatan perilaku supervisi dengan baik seperti melakukan kujungan kelas (obsevasi kelas) secara tertur, mengadakan diskusi kelompok, menjadikan guru mampu melakukan persiapan mengajar dengan baik, mampu mengimplementasikan program kerja, mampu mengadakan evaluasi dan mengembangkan profesi, melakukan analisi daya serap dan ketuntasan belajar siswa setiap selesai ulangan, melakukan analisis target pencapaian kurikulum setiap selesai ulangan, melakukan analisis butir soal setiap selesai ulangan dan membantu dan membimbing siswa yang mengalami kesulitan belajar.

Seperti yang diungkapkan Zahera (1998) bahwa secara umum kepala sekolah yang efektif memfokuskan tindakan-tindakannya pada penetapan tujuan sekolah, mendefinisikan tujuan sekolah dan memberikan sumber-sumber yang diperlukan untuk terjadinya belajar. Selain itu, tindakan kepala sekolah juga untuk mensupervisi, mengevaluasi guru, mengkoordinasikan program pengembangan staf dan menciptakan hubungan kesejahteraan dengan dan antar guru. Dengan demikian semakin membaiknya pembinaan 
kepala sekolah kepada guru akan diikuti secara simultan dengan semakin membaiknya kinerja guru.

Rohani (2004) dalam kajiannya menunjukkan bahwa pembinaan kepala sekolah menurut persepsi guru dan kompensasi berpengaruh signifikan terhadap kinerja guru. Hasil yang berbeda ditunjukkan oleh Ernawati \& Marjono (2007) menemukan bukti bahwa supervisi tidak mempengaruhi kinerja guru sedangkan disiplin kerja mempengaruhi kinerja guru.

Berdasarkan analisis regresi berganda, ditemukan bukti bahwa kompensasi tidak berpengaruh terhadap kinerja guru SMA Negeri I Maumere. Hasil ini dapat diinterpretasikan seharusnya bahwa setiap kenaikkan kebijakan pemberian kompensasi diikuti naiknya kinerja guru SMA Negeri I Maumere. Sehingga berdasarkan hasil temuan dari penelitian ini dapat direkomendasikan bahwa jika institusi ingin mengembangkan kebijakan pemberian sistem kompensasi secara efektif sesuai dengan tujuan yang hendak dicapai yaitu peningkatan kinerja guru, maka kompensasi tersebut harus didistribusikan secara adil.

Keadilan (equality) merupakan keseimbangan antara masukanmasukan yang dibawa masuk oleh individu ke dalam sebuah pekerjaan dengan hasil-hasil yang diperolehnya dari pekerjaan tersebut. Masukan-masukan itu meliputi pengalaman, pendidikan, keahlian khusus, upaya dan waktu kerja. Keluaran-keluarannya meliputi gaji/upah, tunjangantunjangan, pencapaian, pengakuan dan imbalan-imbalan lainnya.

Teori keadilan bermula dengan penegasan bahwa kewajaran dan keadilan adalah penting bagi orangorang. Teori keadilan manyatakan bahwa individu-individu menentukan apakah mereka telah diperlakukan secara wajar dengan membandingkan rasio masukan/keluaran orang lain. Orang lain (atau kelompok orang) ini bisa saja dalam pekerjaan yang sama atau berbeda, di dalam institusi ataupun di luar institusi.

Sebagai institusi pendidikan, SMA Negeri I Maumere dalam menerapkan konsep kompensasi tidak selalu merujuk pada peraturan yang ada dan peraturan tersebut seharusnya lebih mendekatkan pada konsep keadilan, dimana seperti halnya gaji, insentif dan tunjangan yang diterima guru perlu didasarkan pada golongan kepangkatan dan masa kerja serta prestasi kerja guru tersebut. Kondisi ini yang mendorong guru dalam meningkatkan kinerjanya.

Hasil kajian ini tidak mendukung kajian yang dilakukan oleh Gani (2005) menyimpulkan bahwa ada pengaruh yang signifikan antara variabel perilaku tugas, perilaku hubungan gaji, kompensasi dan insentif yang diterima guru terhadap prestasi kerja guru. Aritonang (2005) menunjukkan bahwa terdapat hubungan positif antara kompensasi dan disiplin kerja guru dengan kinerja guru. Penelitian ini juga menyimpulkan bahwa kompensasi kerja memberikan sumbangan sebesar $6,76 \%$ terhadap kinerja guru. Suparwati (1999) menyimpulkan bahwa factor-faktor 
kompensasi seperti gaji, insentif, kesejahteraan dan promosi berpengaruh terhadap kinerja.

\section{DAFTAR PUSTAKA}

Ametembun, NA. 2006. Supervisi Pendidikan. Bandung : Rama.

Arikunto, Suharsimi, Prof Dr. 2006. Dasar - Dasar Supervisi. Jakarta : PT.Rineka Cipta.

Aritonang, T. K,. 2005. Kompensasi Kerja, Disiplin Kerja Guru dan Kinerja Guru SMP Kristen BPK PENABUR Jakarta. Jurnal Pendidikan Penabur, No.04 / Th.IV / Juli 2005

Bishay, A. 1996. Teacher Motivation and Job Satisfaction: A Study Employing the Experience Sampling Method. J. Undergrad. Sci. 3: 147-154.

Fahmi,Irham.2010.Manajemen Kinerja. Bandung. Alfabet

Ferdinand, Augusty, 2006. Metode Penelitian Manajemen. Edisi Kedua, Universitas Diponegoro, Semarang.

Gaffar, F.K. 2005. Perencanaan Pendidikan, Teori dan Metodologi, Jakarta, Depdikbud Ditjen Dikti, Proyek pengembangan LPTK.

Gani, N, 2005. Pengaruh perilaku Pemimpin dan Kompensasi terhadap Prestasi Kerja Guru di Kabupaten Kerom Jayapura. Jurnal Keuangan dan Perbankan, th. IX, no. 3

Ghazanfar, F., Shuai, C., Khan, M.M., \& Mohsin, B. 2011. Study of Relationship between Satisfaction with Compensation and Work Motivation. International Journal of
Business and Social Science, Vol. 2 No. 1

Grossman, R.J. 2000. Emotions at Work, Journal of Health Forum, (HPF) Vol : 43 Iss : 5.

Hamalik, Oemar.2010. Kurikulum dan Pembelajaran.Jakarta;Bumi Aksara

Hasibuan, M. 2007. Manajemen Sumber Daya Manusia. Bumi Aksara, Jakarta.

Mangkunegara, A.A. \& Anwar, P. 2009. Perencanaan dan Pengembangan Sumber Daya Manusia, Edisi Pertama, PT. Refika Aditama, Bandung.

Mathis, L Robert. \& Jackson, H,John., 2006, Human Resource Management (Terjemahan Diana Angelica), Edisi Sepuluh; Jakarta: Salemba Empat.

Miller, A.F.Jr, Hanson, M. 2000. Mismatches, Journal of Acroos The Board (CBR), Vol. 37, Iss:6.

Muljani, N. 2002. Kompensasi sebagai Motivator Untuk Meningkatkan Kinerja Karyawan. Jurnal Manajemen \& Kewirausahaan Vol. 4, No. 2.

Nawawi, H. 2008, Manajemen Sumber Daya Manusia. Cetakan ketiga. Yogyakarta, Gadjah Mada University Press.

Neal, A, \& Grifin. M.A. 1999. Developing a Model of Individual Performance for Human Resource Management, Asia Pasific Journal of Human Resources.

Okorley, E.N.A. \& Boohene, R. 2012. Determinants of Bank Staff Motivation in the Cape 
Coast Metropolis. International Business and Management, Vol 4, No 1, 2012, pp. 121-125

Randy, K.C, Vivienne, W. M. L. \& Thomas L.P.Tang. 2002. Retaining and motivating employees Compensation preferences in Hongkong and China. Personal Review, Vol. 31 No. 4, pp. 402-431.

Rifa'i, M.2006. Administrasi dan Supervisi Pendidikani.Bandung, Jemmars
Rohani. N.K. 2004. Pengaruh

Pembinaan Kepala Sekolah Dan Kompensasi Terhadap Kinerja Guru SLTP Negeri Di Kota Surabaya. Jurnal Pendidikan Dasar, Volume 5 No. 2.

Sahertian, Piet. 2008. Konsep Dasar Dan Teknik Supervisi Pendidikan Dalam Rangka Pengembangan Sumber Daya Manusia. Jakarta : Rineka Cipta. 